\title{
Style-shifting in Usage Instructions of Food, Beverage, and Pharmaceutical Products in Japanese Language
}

\author{
Mulyadi $^{1}$, Suhandano ${ }^{2}$, Aris Munandar ${ }^{3}$ \\ ${ }^{1}$ Faculty of Cultural Sciences, Universitas Gadjah Mada, Yogyakarta, Indonesia \\ ${ }^{2}$ Faculty of Cultural Sciences, Universitas Gadjah Mada, Yogyakarta, Indonesia \\ ${ }^{3}$ Faculty of Cultural Sciences, Universitas Gadjah Mada, Yogyakarta, Indonesia
}

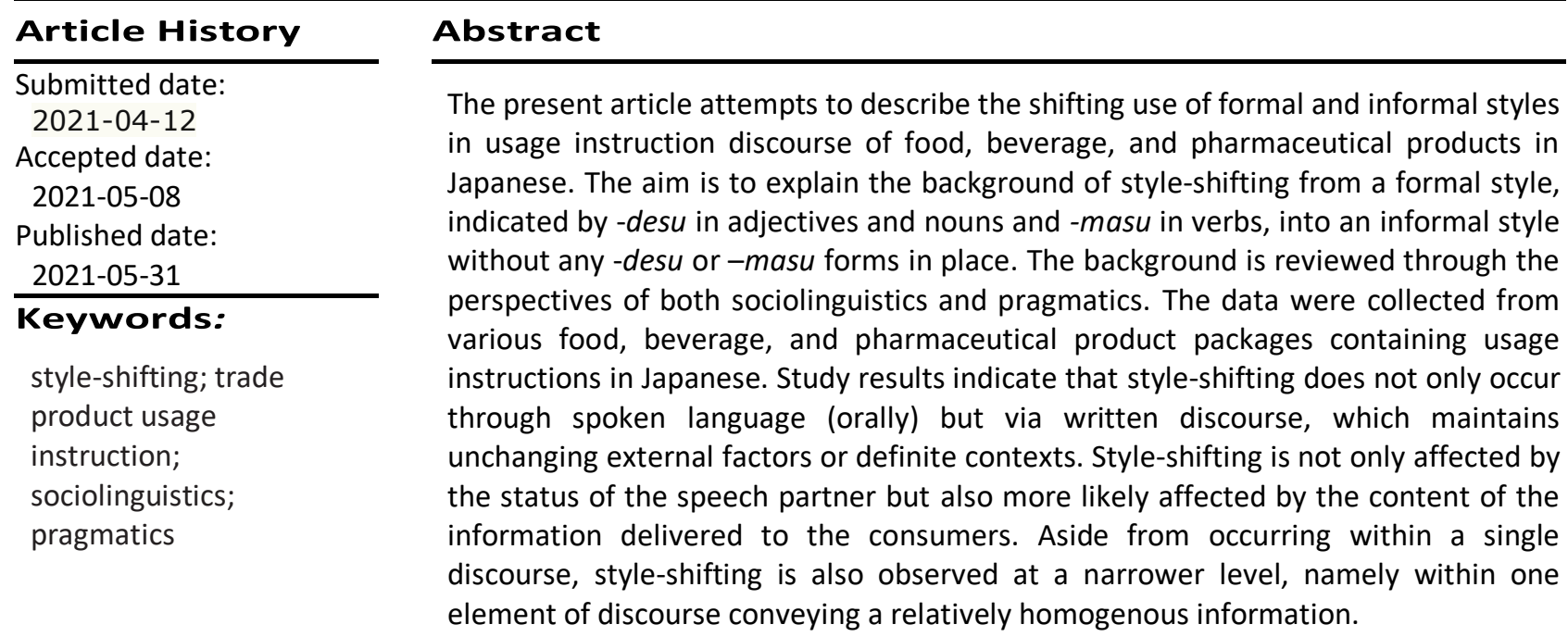

\begin{tabular}{|c|c|}
\hline & Abstrak \\
\hline \multirow{2}{*}{$\begin{array}{l}\text { Kata Kunci: } \\
\text { style-shifting; petunjuk } \\
\text { pemakaian produk } \\
\text { dagang; sosiolinguistik; } \\
\text { pragmatik }\end{array}$} & $\begin{array}{l}\text { (Judul Artikel: Style-shifting pada Wacana Petunjuk Pemakaian Produk Dagang } \\
\text { Makanan, Minuman, dan Obat dalam Bahasa Jepang) }\end{array}$ \\
\hline & $\begin{array}{l}\text { Artikel ini berupaya menjelaskan pemakaian ragam formal dan informal yang terjadi } \\
\text { secara bergantian (shifting) dalam wacana petunjuk pemakaian produk dagang } \\
\text { makanan, minuman, dan obat dalam bahasa Jepang. Tujuannya untuk menjelaskan } \\
\text { latar belakang terjadi pergantian pemakaian ragam formal yang ditandai dengan } \\
\text { bentuk desu pada adjektiva dan nomina, menjadi ragam informal yang tidak m emiliki } \\
\text { tanda desu atau masu. Latar belakang ditinjau baik secara sosiolinguistik maupun } \\
\text { pragmatik. Data diambil dari berbagai macam bungkus produk dagang makanan, } \\
\text { minuman, dan obat yang memuat petunjuk pemakaian dalam bahasa Jepang. Hasil } \\
\text { dari penelitian ini menunjukkan bahwa ternyata style-shifting bukan hanya terjadi } \\
\text { pada ragam lisan tetapi juga terjadi pada wacana tulis yang konteksnya atau faktor } \\
\text { eksternalnya secara pasti tidak pernah berubah. Pergantian pemakaian ragam } \\
\text { tersebut bukan semata dipengaruhi oleh status mitra wicara tetapi lebih cenderung } \\
\text { kepada isi informasi yang disampaikan kepada konsumen. }\end{array}$ \\
\hline
\end{tabular}

Corresponding author:

1 mulyadi@ugm.ac.id

2 suhandano@ugm.ac.id

3 arismunandar@ugm.ac.id 


\section{Introduction}

Style-shifting is commonly affected by extralinguistic factors, yet usage instruction discourse of food, beverage, and pharmaceutical products in Japanese language indicates that style-shifting not only occurs on the basis of speech-related background. Perhaps, it can even be stated that styleshifting in the Japanese case does not correlate with either the availability or lack of changes in speech partner or situation since both of their presence constantly occurs. This implies that styleshifting requires no change in linguistic contexts or external factors. Style-shifting is a most common phenomenon among Japanese-speaking communities in their daily life . In the current study, styleshifting is defined as a shift from formal to informal style or vice versa. In general, style-shifting occurs on account of external factors, as suggested by Labov who cited Gumpers (1964) that 'styleshifting within a fixed context is then seen as the result of the speaker imagining a different audience' (Labov, 2006).

There is still a lack of attention on syntactic studies of styles in the Japanese language (Hasegawa, 2017). Recently, the linguistic phenomenon known as style-shifting is largely observed from the aspect of extralinguistic factors or, in other words, existing studies are mostly based on oral communication data containing amendable speech partners and conditions (Ito, 2012; Jones \& Ono, 2008; Jung, 2015; Lee, 2003; Makino, 2004; Masuda, 2016b; Miyachi et al., 2007; Nomura, 2018; Obana, 2016; Okazaki, 2018; Otsuka, 2004; Terao, 2010) and others. Most researchers analyzed data associated with extralinguistic or social factors. Research on style-shifting unfolding in written language has not garnered much attention. While in fact, written communication is an indispensable part of the numerous facets of Japanese life nowadays.

This article aims to complement previous studies that tend to disregard written data by collecting written data that have a constant context but dynamic use of style. This is, thus, expected to provide an explanation that style-shifting does not only occur on account of extralinguistic factors, but also due to internal factors found within the language itself. These internal factors may be in the form of illocutionary force and theme.

The present article is based on a Japanese social norm specifying that consumers have a social status that is respected by producers. Accordingly, the language style used in usage instruction discourse of food, beverage, pharmaceutical products in Japanese continues to maintain these values of politeness, although the use of style varieties is observed, namely the use of formal and informal styles. Such use of various styles in a single discourse is considered as style shifting. Styleshifting is a part of speech. And, speech can be understood by observing its context. According to Prayitno (2017) context includes time, place, incident, process, condition, cultural background, socio-economic background, and so forth. (Prayitno, 2017). Even though style-shifting is, generally, affected by external factors in the form of changing participant, situation, and the speaker's psychological state, conversely speaking, the stability of these external factors is also still able to bring about style shifting. Thus, the proposed argument is that aside from sociolinguistic factors, it is highly likely that pragmatic factors also have an effect in the shifting of language style.

Studies on shifting in Japanese linguistics have a more extensive theme, some call it speech styleshifting while others simply call it style shifting, in short the term style in this research is sometimes stated as style but there are others who refer to it as speech style. Consequently, the differences between the two need to be explained to easily understand this terminology. There are a number of differences in the definition of speech style and style. Some scholaars state that speech style is the -desu/-masu form supplemented by kenjougo and sonkeigo. Some would refer to this definition of speech style as keigohyougen. Meanwhile, some past scholars consider that style consists of two means of expression namely -desu/-masu and those that are not just -desu/-masu. Perhaps many 
researchers lack interest in exploring this field of study because style is not an overly complicated subject from the perspective of syntactic studies (Hasegawa, 2017). Style is a term of English origin and it is translated into gaya bahasa, gaya in Indonesian (Kridalaksana, 1984). Kridalaksana (1984) defines gaya bahasa as an individual's utilization of linguistic richness in speaking or writing, the use of particular styles to obtain particular effects, and the entirety of a particular group of writers' linguistic characteristics.

The difference of formal and informal varieties in Japanese language can be very clearly observed from its style. The formal style uses -desu/ -masu, while the informal uses da/ suru (Makino,2004). Some refer to the -desu/-masu formal style as teineigo (polite language, courteous language). Teineigo is included in negative politeness (Ito, 2012). Teineigo is an expression that is unassociated with the person or object that is being talked about, but it functions to empathize the interlocutors (Kaneko, 1994). Japanese linguistic experts categorize style into two, namely teineigo (polite form) and futsuugo (plain-form). Taniguchi (2004) specifies style in Japanese language into two, i.e. -desu/-masu tai and hi-desu/-masu tai (Taniguchi, 2004). In terms of its use, style-shifting occurs in both spoken and written forms. In a spoken or written discourse, a speaker may talk using a formal style then shifts to an informal one, or vice versa. Taniguchi (2004) refers to this phenomenon of changing the style being used in a discourse with the term speech style shift. Style is defined as the expression an individual uses depending on the situation and condition of the conversation and it has discursive, psychological, and social effects (Shibuya, 2015). Style in the form of desu-masu is called teineigo or performative honorification (Hasegawa, 2017). Furthermore, Shibuya (2015) posits that factors affecting style usage include statuses attached to the interlocutors such as home town, gender, age, occupation; it also depends on the type of relationship fostered between the speaker and the interlocutor, for instance: senior junior or close-not close; and the state of communication at the time, i.e. formal or informal.

Previous studies on style-shifting tend to use oral based data with analyses associated with the presence of the participants. As a result, it is the participants' social variables that have an effect on style shifting. Makino (2004) examined shifting politeness in spoken discourse from formal to informal and vice versa from the standard language to the dialect used in Tsugaru, and Tokyo's Shitamachi dialect. It is stated in the study that social variables having influence on style-shifting include relationship among the participants, i.e. newly introduced or closely acquainted, as well as age variable, i.e. young and old. In the same light Li (2003) also examined style-shifting under formal conditions with spoken data of conversational discourse carried out by Japanese language learners and native Japanese speakers, which produced perspectives of different degrees of politeness. Politeness in Japanese society can be expressed through gestures, facial expressions, tone, or appearance depending on the degree of politeness. Additionally, there is also a linguistic behavior in Japanese language known as keigo (Ofuka et al., 2000)

Observed from its function, teineigo containing the -desu/masu form above, is further considered by Ide (1989) to indicate a formal style and it is a type of honorifics to the conversation partner (addressee honorific) (Ide, 1989). As for the function of the plain-form, it is used as a self expression (mumbling/muttering), and repeating the utterance of a conversation partner or information in the form of directive expression (Saito, 2010). Meanwhile, Terao (2010) states that futsuugo or non-desu/-masu functions as a quotation indicator and embedded clause in sentences. In negative sentences the use of the non-desu/-masu form is prioritized over the use of the -desu/masu form (Terao, 2010).

Style-shifting is a communication competence meant to facilitate the relationship fostered between conversation participants, and this phenomenon is knowledge that Japanese people 
naturally acquire (Terao, 2010). According to Ikuta and Ide (1989) style-shifting occurs on account of: social factors, conversation partner's psychological state, and development of discourse structure (Ishizaki, 2000). Usami in Ishizaki (2000) explains that style-shifting occurs on the basis of psychological and linguistic context-related factors.

Every speech found in the Japanese language is always associated with numerous factors in order for it to be expressed politely in accordance with the norms of Japanese society. Linguistic politeness is a complicated discussion influenced by various factors that include the conversation participants' desire, position or relationship between the participants, social norms that apply to the participants, the participants' interpretation of social rules, and contexts during the interaction (Liu \& Allen, 2014). Furthermore, Liu and Allen (2014) suggest that an influential factor in using or choosing an appropriate style in Japanese is not only social norms, but an understanding (wakimae) of one's position (tachiba) in the society and one's relationship with the interlocutor. This is considered the second layer in analyzing politeness in Japanese language. Ishizaki posits that speech level shift occurs due to tachiba and speech content (Ishizaki, 2000). Adachi (1995) in Ishizaki states that a shift to the teinei form expresses the objective stance of the speaker while a shift to the casual form is an emotional expression or an expression of personal conditions. Okamoto (1995) in Ishizaki (2000) explains that style-shifting is affected by: 1 . Whether a situation is formal or not; 2 . Whether the conversation partner is the entire class; 3. Whether speaking on a personal or professional level; 4. Whether the conversation partner is considered an in-group or an out-group. Moreover, speech level shift is caused by a shift of bamen or conversation conditions (Terao, 2010). A research by Otsuka (2004) which collected data from the debates of parliamentary members indicates that shifts between -desu/masu and non-desu/-masu forms depend on the content of the statement, i.e. the non -desu/masu style is used when they wish to convey something, whereas the -desu/-masu style is employed when conveying general information (Otsuka, 2004).

Participants of a conversation have different degrees of freedom in choosing the style they wish to employ, the inferior party has less freedom than the superior in choosing style. A lecturer has the option of using both formal or informal styles when communicating with a student. A lecturer may use the formal style when speaking before all the students in the classroom, but may opt to use the informal style when speaking outside of class. Meanwhile, students will keep using the formal style when speaking with their lecturer in both formal or casual situations (Masuda, 2016a).

Shibuya (2015) suggests that style-shifting in the works of Santo Kyoden is influenced by the sentence structure, i.e. whether it is in narrative or dialog form, social attributes (gender, age, social class, etc.), and the writer's intent to assert psychological or social effects, and influence of the discourse's theme.

Style-shifting from informal to formal is observed in daily conversations. Such style-shifting occurs in order to express complaints, accusations, critiques, and disagreements (Takamiya, 2017). Furthermore, Takamiya (2017) explains that the function of style includes: 1 . To instill understanding and gain the conversation partner's acceptance of the speaker's intent by repeating the formal style for emphasis; 2 . To get conversation partners to agree to the speaker's opinion and to calm the conversation partner's anger, as observed in formal style that appears in conversations that are essentially informal in nature; 3 . To obtain sandou (agreement from the conversation partner) when giving negative comments about a third party.

Style-shifting occurs because of change in participants, rhetorical shifts, conversation conditions at the time, and rhetorical switching (Eckert \& Rickford, 2002). Taniguchi (2004) suggests that styleshifting functions to express an impression or opinion, to indicate an amount, a concrete example, etc., and to explain a background of an imagination or memory. 


\section{Method}

The data for the present study were collected through observation of authentic data (Leech, 2014) obtained from written discourses on packages of food, beverage, and pharmaceutical products in Japan written in Japanese and marketed in Japan. The data were transliterated into Romaji. The collected data are a standard variant of the Japanese language. The object of research was chosen under the assumption that these products are exposed to all tiers of society, or in other words, these are products that Japanese generally consume, although in some cases there are some products catering to a particular market share based on a particular social group. Nonetheless, this study employed data taken from trade products that do not target specific social groups, and that do not correlate with particular social targets or backgrounds. This is a descriptive-qualitative study, the research data consist of speeches in the form of sentences with -desu/-masu and non -desu/masu forms found in usage instruction discourses of food, beverage, and pharmaceutical products.

The source of data in the form of trade product usage instruction discourses are monologs with speech participants in the form of a particular consumer and a company (producer). These discourses had already been calculated and fabricated before being conveyed to their interlocutors.

Generally speaking, these instructions of use are made to communicate to the consumers how they can gain optimal benefits from the product they purchase. Furthermore, the discourses for these product usage instructions have been made with the purpose of being easily accessible, legible, and containing beneficial information for the interlocutors. These three criteria were set as an assessment standard in a manual making contest held by the Technical Communicator Foundation in Japan in 2015 (Ippan Zaidan Houjin Tekunikaru Komyunikeetaa Kyoukai, 2015).

The data were gathered by classifying sentences with -desu/-masu form into the formal style and those with non-desu/-masu form into the informal style. Additionally, elements of discourse were also identified in terms of style use composition, namely discourses using only formal style, only informal style, or those using a combination of both formal and informal styles.

The data were subsequently analyzed by identifying the characteristics of linguistic styles, as well as the sequence when formal and informal styles appear, be it in a single discourse or in a greater scope, namely those occurring within a single discourse element. The background and content of style usage were then interpreted based on their appearance in their respective elements, which contain a specific information conveyed to the consumers.

\section{Results and Discussion}

The research data here are not entirely presented in the article but it is shown based on the availability of style markers, namely those containing the morphemes -desu or-masu.

Evidence of style-shifting in Japanese written discourses can be observed in Table 1, Table 2, and Table 3. Each table is the results of specifications within a discourse by mentioning all the elements written on the product packaging. Not all product usage instruction data contain a uniformed amount of discourse elements, but there are a number of universal elements found in the data such as product composition, method of use, warning, and company name or address.

Apparently, these three discourses of product usage instructions employ a variety of styles. In certain discourse element the formal style is used, but in other elements the informal style is employed, there is even the simultaneous use of both formal and informal styles within one element of discourse. This is the phenomenon that the authors define as style shifting.

Generally speaking, both formal and informal styles in Japanese language can occur using imperative, adjectival, nominal, and verbal predicates. However, the data acquired in the study did not indicate any sentence containing verbal predicate in the informal style, all sentences with verbal predicate were in the -masu form or formal style, and imperative sentences in the te kudasai form. 
In other words, it can be stated that style-shifting only occurs in sentences with nominal predicate. This is apparent in the following sentences.

(1) また、生地表面の黒い粒は小麦肧芽が焼かれたものです。

Mata, kiji hyōmen no kuroi tsubu wa komugi haiga ga yakareta mono desu.

'in addition, the black grains on the dough's surface are baked wheat germ'

(2) ‥食塩、小麦胚芽、膨脹剂、乳化剂（大豆由来）、香料（乳由来）

shokuen, komugi haiga, bōchō-zai, nyūkazai (daizu yurai), kōryō (chichi yurai)

'... salt, wheat germ, leavening agent, emulsifier (soy-based), flavoring (dairy-based)'

Sentence (1) is a part of speech categorized in the warning discourse element, while sentence (2) is categorized in the composition element. Sentence (1) is a formal style speech because a politeness marker, namely - desu, is found at the end of the sentence. Meanwhile, in sentence (2) above the politeness marker -desu is not found, specifying the speech as an informal style.

Upon observation of predicates in the sentences, sentences that have two style variants are those with nominal predicates. Meanwhile, closer examination of the respective elements indicates that formal and informal styles can appear in certain elements. As shown in Table 1, Table 2, and Table 3, the formal style appears in the following elements: introduction (1) (2), information on expiry date (1) (2), storage method (1), warning (1) (2) (3), information on production site (2), serving method (2), and method of use (2) (3).

Meanwhile, the informal style is used in the following elements: composition (Table 1), (Table 2), (Table 3), volume (Table 1), (Table 2), (Table 3), information concerning the maker's name (Table 1) web address (Table 1), introduction (Table 2) (Table 3), name of additives (Table 2), name of country producing the ingredient (Table 2), storage method (Table 2), name of distributor (Table 2), factory address (Table 2), serving method (Table 2), warning (Table 3), and company address (Table 3).

Aside from appearing in the data of a usage instruction discourse of a product, style-shifting can actually appear at a lower level, namely in its discourse element. The discourse elements containing both styles are the introduction on the packaging of a beverage product and the warning on the packaging of a pharmaceutical product.

The style-shifting observed in one element is in the form of the following sentences. This element contains three sentences and style-shifting occurs from formal to informal then back to formal, as shown in sentences (3), (4), and (5) below.

$$
\text { カフェインを気にせず飲めるインスタント緑茶です。[FORMAL] }
$$

Kafein o ki ni sezu nomeru insutanto ryokucha desu

'Instant green tea you can drink without worrying about caffeine.'

Sentence (3) has a nominal predicate and it is a formal style of speech as we can find the morpheme -desu at the end of the sentence, which is a formal style marker for sentences with adjectival or nominal predicate. In the case of sentence (3) it has a nominal predicate.

(4) カフェインレスだからおやすみ前のリラックスタイムにもおすすめ。 [INFORMAL] Kafeinresu dakara oyasumi mae no rirakkusu taimu ni mo osusume.

'because it's caffeine-free, it is also recommended for relaxing before going to bed'

Sentence (4) is a speech with an informal style because no formal marker, or any marker in this case, is found at the end of the sentence.

(5) 㛜選された国産茶葉と宇治抹茶による本格的な味わいをカフェインレスでお楽し

$$
\text { みください。[FORMAL] }
$$


Gensen sareta kokusan chaba to uji matcha ni yoru honkaku-tekina ajiwai o kafeinresu de otanoshimi kudasai

'Enjoy the authentic taste of this caffeine-free carefully selected domestic tea leaves and uji matcha'

Sentence (5) is a formal style since the honorific style marker of o-kudasai for verbal predicate is observed. Research data indicate that this element commonly only contains the formal style. However, for the warning element in the usage instructions of a pharmaceutical product from Etude House contains both formal and informal styles.

The shifting model's characteristic is not too apparent, but speeches with verbal predicates tend to use the formal style. Meanwhile, the discourse element that tend to use the formal style is warning, whereas the one containing the informal style is composition.

The use of noun word class, which tends to be informal speeches, is observed in names of element, names of chemical that make up the product, and company address (see table). The verb word class is mostly used in conveying significant information or warning, and recommendation or prohibition. Or information that requires the interlocutor to avoid or do something. The consumer's action is in the interest of common good so that neither the company nor consumer are harmed.

Table 1. FOOD: Alfort Chocolate (8 elements of discourse, formal and informal)

\begin{tabular}{|c|c|c|c|}
\hline No & Elements & Style & Examples \\
\hline 1 & Introduction & $\begin{array}{l}\text { FORMAL } \\
\text { (morpheme -desu } \\
\text { at end of sentence }\end{array}$ & $\begin{array}{l}\text { Zenryuuko-iri no daijesutibu bisuketto o } \\
\text { koubashiku yaki age, hansen o katachi dotta } \\
\text { chokoreeto to kumiawaseta orijinaruna } \\
\text { chokoreetobisuketto desu. } \\
\text { 'Original sail-shaped chocolate biscuits are } \\
\text { made by baking digestive biscuits containing } \\
\text { whole grains thus producing a fragrant aroma.' }\end{array}$ \\
\hline 2 & Composition & INFORMAL* & $\begin{array}{l}\text {...shokuen, komugi haiga, bouchou-zai, } \\
\text { nyuukazai (daizu yurai), kouryou (chichi yurai) } \\
\text { '... salt, wheat germ, leavening agent, emulsifier } \\
\text { (soy-based), flavoring (dairy-based)' }\end{array}$ \\
\hline 3 & Content Volume & INFORMAL & $\begin{array}{l}204 \mathrm{G} \text { (kosou-shi-komi) } \\
\text { '204 g (including paper ackaging)' }\end{array}$ \\
\hline 4 & $\begin{array}{l}\text { Appropriate Time } \\
\text { of Consumption }\end{array}$ & $\begin{array}{l}\text { FORMAL } \\
\text { (morpheme - } \\
\text { masu at end of } \\
\text { sentence) }\end{array}$ & $\begin{array}{l}\text { Kono men no hidari kabu ni hyouji shite arimasu } \\
\text { 'it is presented at the bottom left hand side of } \\
\text { the page' }\end{array}$ \\
\hline 5 & Storage Method & $\begin{array}{l}\text { FORMAL } \\
\text { (morpheme te } \\
\text { kudasai at end of } \\
\text { sentence) }\end{array}$ & $\begin{array}{l}\text { chokusha nikkou o sake, } 28^{\circ} \mathrm{C} \text { ika de hozon shite } \\
\text { kudasai. } \\
\text { 'Avoid direct exposure to sunlight and keep in } \\
\text { temperature } 28^{\circ} \mathrm{C} \text {.' }\end{array}$ \\
\hline 6 & Manufacturer & INFORMAL* & $\begin{array}{l}\text { Seizoushokoyuukigou wa shoumi kigen no shita } \\
\text { ni hyouji } \\
\text { 'The name of the company is presented below } \\
\text { the best before date' }\end{array}$ \\
\hline 7 & $\begin{array}{l}\text { Warning during } \\
\text { Use }\end{array}$ & $\begin{array}{l}\text { FORMAL } \\
\text { (morpheme-desu } \\
\text { at end of } \\
\text { sentence) }\end{array}$ & $\begin{array}{l}\text { Mata, kiji hyoumen no kuroi tsubu wa komugi } \\
\text { haiga ga yakareta mono desu. } \\
\text { 'in addition, the black grains on the dough's } \\
\text { surface are baked wheat germ.' }\end{array}$ \\
\hline 8 & $\begin{array}{l}\text { Warning during } \\
\text { Use }\end{array}$ & INFORMAL* & $\begin{array}{l}\text { Hoomu peeji htttp://www.bourbon.co.jp/ } \\
\text { 'Home page htttp://www.bourbon.co.jp/' }\end{array}$ \\
\hline
\end{tabular}

Note: * neither desu nor masu morphemes were found at end of the sentence 
Mulyadi, M., Suhandano, S., Munandar, A., (2021). Style-shifting in Usage Instructions of Food, Beverage, and Pharmaceutical Products in Japanese Language. Japanese Research on Linguistics, Literature, and Culture 3 (2), 100-112. https://doi.org/10.33633/ir.v3i2.4589

Table 2. BEVERAGE: Instanto Ryokucha

\begin{tabular}{|c|c|c|c|c|}
\hline No & Elements & \multicolumn{2}{|c|}{ Style } & \multirow[b]{2}{*}{$\begin{array}{l}\text { Examples } \\
\text { Kafein o ki ni sezu nomeru insutanto ryokucha desu } \\
\text { Kafeinresu dakara oyasumi mae no rirakkusu taimu } \\
\text { ni mo osusume. } \\
\text { Gensen sareta kokusan chaba to uji matcha ni yoru } \\
\text { honkaku-tekina ajiwai o kafeinresu de otanoshimi } \\
\text { kudasai } \\
\text { 'instant green tea you can drink without worrying } \\
\text { about caffeine.' } \\
\text { 'because it's caffeine-free, it is also recommended } \\
\text { for relaxing before going to bed.' } \\
\text { 'enjoy the authentic taste of this carefully selected } \\
\text { domestic tea leaves and uji matcha.' }\end{array}$} \\
\hline 1 & Introduction & $\begin{array}{l}\text { FORMAL (morpheme- } \\
\text { desu at end of } \\
\text { sentence no. } 1 \text { and } \\
\text { honorific style of } o- \\
\text { kudasai in sentence } \\
\text { no. 3) }\end{array}$ & $\begin{array}{l}\text { INFORMAL } \\
\text { (neither desu nor } \\
\text { masu morphemes } \\
\text { were found at end of } \\
\text { sentence no. 2) }\end{array}$ & \\
\hline \multirow[t]{3}{*}{2} & Composition & & INFORMAL* & $\begin{array}{l}\text { Ryokucha (sencha, matcha), dekisutorin } \\
\text { 'Green tea (sencha, matcha), dextrin.' }\end{array}$ \\
\hline & Additives & & INFORMAL* & $\begin{array}{l}\text { Bitamin C } \\
\text { 'Vitamin C' }\end{array}$ \\
\hline & $\begin{array}{l}\text { Ingredient } \\
\text { Producing } \\
\text { Country }\end{array}$ & & INFORMAL* & $\begin{array}{l}\text { Nihon (sencha, matcha) } \\
\text { 'Japan (sencha, matcha)' }\end{array}$ \\
\hline 3 & $\begin{array}{l}\text { Content } \\
\text { Volume }\end{array}$ & & INFORMAL* & $\begin{array}{l}40 g \\
' 40 g '\end{array}$ \\
\hline 4 & $\begin{array}{l}\text { Appropriate } \\
\text { Time of } \\
\text { Consumption }\end{array}$ & $\begin{array}{l}\text { FORMAL (morpheme - } \\
\text { masu at end of } \\
\text { sentence) }\end{array}$ & & $\begin{array}{l}\text { Kono men no hidari kabu ni hyooji shite arimasu } \\
\text { 'it is presented at the bottom left hand side of the } \\
\text { page' }\end{array}$ \\
\hline 5 & $\begin{array}{l}\text { Storage } \\
\text { Method }\end{array}$ & & INFORMAL* & $\begin{array}{l}\text { Chokusha nikkou oyobi kouon tashitsu o sakete } \\
\text { hozon } \\
\text { 'Store in a place with low humidity and no direct } \\
\text { exposure to sunlight' }\end{array}$ \\
\hline 6 & Sales Agent & & INFORMAL* & $\begin{array}{l}\text { Mitsui Norin Co. Ltd. 105-84271, 1-2-9 Nishi } \\
\text { Sinbashi, Minato-ku, Tokyo }\end{array}$ \\
\hline \multirow[t]{2}{*}{7} & $\begin{array}{l}\text { Factory } \\
\text { Address }\end{array}$ & & INFORMAL & $\begin{array}{l}\text { DNP Housou Co. Ltd. 2-10-25 Akabane Minami, Kita- } \\
\text { ku, Tokyo }\end{array}$ \\
\hline & $\begin{array}{l}\text { Information } \\
\text { on } \\
\text { Processing } \\
\text { Site }\end{array}$ & $\begin{array}{l}\text { FORMAL (morpheme - } \\
\text { masu at end of } \\
\text { sentence) }\end{array}$ & & $\begin{array}{l}\text { Kono seihin wa kokunai de seizou shiteimasu } \\
\text { 'This product was processed domestically' }\end{array}$ \\
\hline \multirow[t]{2}{*}{8} & $\begin{array}{l}\text { Usage } \\
\text { Warning }\end{array}$ & $\begin{array}{l}\text { Formal (morpheme - } \\
\text { masu at end of } \\
\text { sentence) }\end{array}$ & & $\begin{array}{l}\text { Fukurouchi ni suibun ga fuchaku suruto funmatsu ga } \\
\text { tokete katamaru baai ga arimasu. } \\
\text { 'powder dissolve and harden if moisture develops in } \\
\text { the package.' }\end{array}$ \\
\hline & $\begin{array}{l}\text { Serving } \\
\text { Method }\end{array}$ & $\begin{array}{l}\text { FORMAL (morpheme - } \\
\text { te kudasai at end of } \\
\text { sentence } 1 \text { and desu } \\
\text { at end of sentence 2) }\end{array}$ & $\begin{array}{l}\text { INFORMAL (neither } \\
\text { desu nor masu } \\
\text { morphemes were } \\
\text { found in the heading } \\
\text { "hotto no baai") }\end{array}$ & $\begin{array}{l}\text { Hotto no baai. } \\
\text { Kosaji ni karuku ippai-bun (yaku } 0.7 \mathrm{~g} \text { ) o yunomi ni } \\
\text { irete kudasai. } \\
\text { Ato wa oyu o sosogu dake de, dekiagari desu. ( } 80 \text { - } \\
100 \mathrm{ml} \text { ) } \\
\text { 'when hot pour a tea spoon (approximately } 0.7 \mathrm{~g} \text { ) } \\
\text { into a tea cup. Next you should simply add hot } \\
\text { water }(80-100 \mathrm{ml}) . \text {.' }\end{array}$ \\
\hline
\end{tabular}

Note: * neither desu nor masu morphemes were found at end of the sentence 
Mulyadi, M., Suhandano, S., Munandar, A., (2021). Style-shifting in Usage Instructions of Food, Beverage, and Pharmaceutical Products in Japanese Language. Japanese Research on Linguistics, Literature, and Culture 3 (2), 100-112. https://doi.org/10.33633/ir.v3i2.4589

Table 3. PHARMACEUTICAL: Etude House

\begin{tabular}{|c|c|c|c|c|}
\hline No & Elements & \multicolumn{2}{|c|}{ Linguistic Style } & Examples \\
\hline 1 & Introduction & & INFORMAL* & $\begin{array}{l}\text { Sukoyakana matsuge ni michibiku essensu \& } \\
\text { beesumasukara } \\
\text { 'mascara base \& essence for healthy eyelashes' }\end{array}$ \\
\hline 2 & Composition & & INFORMAL* & $\begin{array}{l}\text { Biochin, (akurireetsu/ akuriru san arukiru (C } 10 \text { - } \\
\text { 30)) kurosuporimā, pegu - } 14 \mathrm{M} \text {, torometamin, } \\
\text { EDTA - } 2 \text { Na, fenokitsuetanooru } \\
\text { 'Biotin, (acrylates/ acrylic acid alkyl (c10-30) } \\
\text { crosspolymer, PEG -14M, tromethamine, EDTA-2Na, } \\
\text { Phenoxyethanol' }\end{array}$ \\
\hline 3 & $\begin{array}{l}\text { Method of } \\
\text { Use }\end{array}$ & $\begin{array}{l}\text { FORMAL } \\
\text { (morpheme - } \\
\text { masu at end of } \\
\text { sentence) }\end{array}$ & & $\begin{array}{l}\text { Sengan-go, seiketsuna matsuge ni go shiyou } \\
\text { kudasai. Tekiryō o tori-jou matsuge-ka matsuge ni } \\
\text { tofu shimasu. } \\
\text { 'Apply on clean eyelashes after washing your face. } \\
\text { Apply appropriate amount on top and bottom } \\
\text { lashes' }\end{array}$ \\
\hline 4 & Warning & $\begin{array}{l}\text { FORMAL } \\
\text { (morpheme - } \\
\text { masu at end of } \\
\text { sentence) }\end{array}$ & INFORMAL* & $\begin{array}{l}\text { Sonomama shiyou o tsudzukemasu to, shōjō o akka } \\
\text { saseru koto ga arimasu node, pibuka senmon'l nado } \\
\text { ni go sōdan sareru koto o osusume shimasu. } \\
\text { (1) Shiyou-chuu, akami, hare, kayumi, Shigeki nado } \\
\text { no ijou ga arawareta baai. } \\
\text { (2) Shiyou shita o hada ni, chokusha nikkou ga } \\
\text { atatte jouki no youna ijou ga arawareta baai. } \\
\text { 'Continous use may aggrevate symptomps; it is } \\
\text { recommended that you consult a dermatologist. } \\
\text { When there are abnormalities such as redness, } \\
\text { swelling, itch, and irritation developing during use. } \\
\text { When applied skin is in direct contact with sunlight } \\
\text { and the above abmormalities develop.' }\end{array}$ \\
\hline 5 & Volume & & INFORMAL* & $\begin{array}{l}D \text { rasshu biyō-eki: } 6 \mathrm{~mL} \text { D rasshuessensupuraimā } 8 \\
m L \\
\text { 'D rush beauty essence: } 6 \mathrm{~mL}, \mathrm{D} \text { rush essence primer } \\
8 \mathrm{~mL}^{\prime}\end{array}$ \\
\hline 6 & $\begin{array}{l}\text { Company } \\
\text { Address }\end{array}$ & & INFORMAL* & $\begin{array}{l}\text { Amoore Pacific Japan KK/ 2-1-1 Tora no Mon, } \\
\text { Minatao-ku, Tokyo }\end{array}$ \\
\hline
\end{tabular}

Note: * neither desu nor masu morphemes were found at end of the sentence

According to the above data it is known that various style usages are found in a single discourse, even in one element of discourse. Trade product usage instruction discourse is, generally, directed at a conversation partner with a higher status, namely consumers who in the Japanese world of business should be afforded proper hospitality, a similar treatment given to respect one's guest. Since the interlocutors are people who should be respected, then it is only suitable that polite expressions capable of avoiding any discomfort on the interlocutors' side be employed in the communication. Expressing such politeness in Japanese depends on social structure and appropriateness of the situation when the speech act is carried out. Additionally, the most prominent matter to be considered in using this style is whether the participants have a close relationship or not, and the participants' position as an out-group or an in-group (soto or uchi). The participants in the product usage instruction discourse are the producers and consumers who have a soto and uchi relationship, which means that the relationship they have is not a close one making the use of the formal or polite form, which is commonly marked by speeches containing sentences in the -desu-/masu form, a natural occurrence. However, it is not that simple, as shown in the data. 
By examining Table 1, Table 2, and Table 3 it can be understood that the style usage in the discourses varies, even within a single element as shown in Table 2 under the discourse elements of introduction and serving method, and Table 3 under the element of warning.

The style choice made might neither be due to the element nor the product. Based on the study results no data were found to consistently contain discourse element that constantly employ two styles in a simultaneous manner. Moreover, none of the data indicate any product usage instruction discourse using one style in its entirety, all utilized both styles simultaneously. These styles possess functions that are unavoidable for conveying information in product usage instruction discourse in the Japanese language.

The function of the formal style in trade product discourse is considerably complex. However, when we observe the data, it is apparent that the use of the formal style in this case, aside from a general adherence to prevailing social rules in daily conversation, is to maintain one's distance from the interlocutors. There are also internal factors found within language itself that emerge. Speeches that function to maintain distance are seen in the data containing sentences with -desu/-masu form. This indicates that product usage instructions are directed at speech partners who have a socially distant relationship with the speaker. Additionally, the use of polite directive speech, which contains a relatively high illocutionary force, is also observed in the data. Such type of speech is often found in discourse element of warning and usage method.

In the following, we can examine the data as written in Table 1, a food product usage instruction discourse in the introduction element. The sentence is as follows:

Zenryuuko-iri no daijesutibubisuketto o koubashiku yaki age, hansen o katachi dotta chokoreeto to kumiawaseta orijinaruna chokoreetobisuketto desu.

'original sail-shaped chocolate biscuits are made by baking digestive biscuits containing whole grains thus producing a fragrant aroma.'

The speech found in the introduction element above is meant to invite consumers and make them feel safe and to indicate a luxury in enjoying the product. At the very least, there is an invitation to enjoy the product in this element. So, this sentence is a directive speech, since it requests the speech partner to do something. Accordingly, the request is conveyed in a manner that would not offend the speech partner, which is why a polite and formal style of speech was used. Ide (1983) states that polite speeches function to ease communication. Such a background also applies for other sentences.

Another finding refers to information on product manufacturing site, which is expressed using the formal form as seen in 2 product processing site elements in the sentence below. While in fact, company address is mostly written in the informal style.

Kono seihin wa kokunai de seizou shiteimasu

'This product was processed domestically'

The above sentence is a formal style of speech as it is indicated with the morpheme -masu in its verbal predicate. Although the above speech merely provides information about the products domestic processing site, the conveyed information is expected to provide customers, particularly domestic customers in Japan, with a sense of safety without any concern. Since this is information of utmost significance, it needs to be emphasized by using the formal style of speech. The consumers feel safer with domestic products than those made in other countries, particularly in the case of this product the countries producing the materials are not developed countries.

Meanwhile, the informal style in the written form is used for information containing neither invitation nor prohibition, but for light information and simple announcements. Some examples include information about composition, food-producing country, address, and so forth. Such types of information are considered nonessential or dispensible information since disposing them pose 
no health hazard to the consumers. According to Obana (2016), the desu/masu forms function in plus-level shifts (shifts from plain to polite forms, masu/desu), which are triggered when the speaker experiences cautious, attentive, thoughtful and/or grateful feelings at a certain time of interaction, which conforms to the original nature of honorifics. Although Obana does not assert that the plain form automatically bears the opposite function of desu/masu, based on the data provided in the table above, it can be concluded that the use of hi-desumasu tends to be found in information that are not too important. Hence, the use of hidesumasu may be considered due to the absence of factors that can trigger the use of the formal form as Obana mentioned, namely the absence of caution, attention, grateful and/or thoughtful feelings concerning the information conveyed to the consumers. In other words, if the information were not conveyed to the consumers, it would not put the consumers health at risk.

However, upon closer observation, by writing them in short structures like headings of discourse element, the use of such speech, aside from not having high illocutionary force, can also be intended for easier reading, which is one of the assessment criteria in a competition to make product usage manual held by the Technical Communicator Foundation in 2015.

\section{Conclusion}

Evidently, style-shifting does not only occur in a dynamic context, as many researchers have outlined through various studies, but it also occurs in discourses that have a constant context, such as trade product usage instruction, which only has a formal situation and interlocutors with a higher status than the speaker.

The content of the information is an aspect that cannot be ignored in the shifting phenomenon found in written discourses. The interlocutor's status or situation does not have much influence in style-shifting. Based on the current study, we are certain that style-shifting in the written form, aside from being affected by the writer's imagination of the situation and interlocutor, is known to use the -desu/-masu form not only as a formal expression influenced by situation or status of interlocutors. We believe that style-shifting in written discourse without any change of situation and interlocutor when expressed has a significant correlation with the content or theme of the conversation. The high illocutionary force that supposedly burdens the speech partner also affects the use of formal style in this discourse.

The current research on style-shifting is significantly limited to shifting the only style, and subsequent studies can study shifting of various other speech levels such as the honorific form and the refined form, register, and so on. In addition, the present study has yet to touch on product usage instructions targeting a particular market segment with the assumption that the interlocutor's social status level affects the degree of speech formality, in which its degree of politeness may perhaps be explained. Assuming that product usage instructions use polite and formal language, further studies on the degrees of formality in the Japanese language have written discourse by examining word choice such as katai kotoba need to be carried out.

\section{References}

Eckert, P., \& Rickford, J. R. (Eds.). (2002). Style and Sociolinguistic Variation. Cambridge University Press.

Hasegawa, N. (2017). Honorifics. In Honorifics (2nd ed.). John Wiley and Sons, Inc. 
Ide, S. (1989). Formal forms and discernment: Two neglected aspects of universals of linguistic politeness. Multilingua - Journal of Cross-Cultural and Interlanguage Communication, 8(2-3), 223-248. https://doi.org/10.1515/mult.1989.8.2-3.223

Ippan Zaidan Houjin Tekunikaru Komyunikeetaa Kyoukai. (2015). Nihon Manyuaru Kontesuto 2015 Sanpuru Shuu. 16.

Ishizaki, A. (2000). Denwa Renraku no Kaiwa ni Okeru Supiichi Reberu Shifuto.

Ito, N. (2012). The Polite Negative Predicate Verb Forms in Japanese, "masen" "naidesu": Approach through Politeness Theory. Suzuka Kokusai University Bulletin C A M A N A, No. 19.

Jones, K., \& Ono, T. (Eds.). (2008). Style-shifting in Japanese. John Benjamins Pub.

Jung, H. (2015). Speech Style Shifts in Korean and Japanese Tv Cooking Shows: A Comparative Study (Dissertation). ProQuest LLC.

Kaneko, Y. (1994). Wakamono to Keigo Hyougen. Ueda Joshi Tanki Daigaku Bulletin, 17.

Kridalaksana, H. (1984). Kamus Linguistik (2nd ed.). PT Gramedia.

Labov, W. (2006). Social Stratification of English in New York City (2nd ed.). Cambridge University Press.

Lee, G. Y. (2003). Foomaru na Danwa deno Hi desu/masu Keishiki no Kirikae: Nihongo Bogowasha to Chuukan Gengo Washa no Hikaku. Handai Shakai Gengokaku Kenkyuu Nooto, 5, P.79-P.96.

Leech, G. N. (2014). The pragmatics of politeness. Oxford University Press.

Liu, X., \& Allen, T. J. (2014). A Study of Linguistic Politeness in Japanese. Open Journal of Modern Linguistics, 04(05), 651-663. https://doi.org/10.4236/ojml.2014.45056

Makino, Y. (2004). "Teineita/Futsuutai"to "Kyoutsuugo Keishiki/Hougen Keishiki" no Kirikae: Tsugaru, Kouchi, Toukyou Shitamachi Hougen no Taishou Kenkyuu. Handai Shakai Gengogaku Kenkyuu Nooto, 6.

Masuda, K. (2016a). Style-shifting in student-professor conversations. Journal of Pragmatics, 101, 101-117. https://doi.org/10.1016/j.pragma.2016.05.012

Miyachi, A., Kitamura, M., Kato, J., Ishikawa, M., Kato, Y., \& Azuma, H. (2007). Kyouzaisei kara Mita 'desu/masu'no Shoukinou. Shizen Gendo Shori, 14(3).

Nomura, K. (2018). A study on the spread of the usage of an auxiliary verb "desu." Mukogawa Joshi Daigaku Gakkou Kyouiku Sentaa Nenpou, 3.

Obana, Y. (2016). Speech level shifts in Japanese: A different perspective. the application of symbolic interactionist role theory. Pragmatics, 26(2), 247-290. https://doi.org/10.1075/ prag.26.2.04oba 
Ofuka, E., McKeown, J. D., Waterman, M. G., \& Roach, P. J. (2000). Prosodic cues for rated politeness in Japanese speech. Speech Communication, 32(3), 199-217. https://doi.org/10.1016/S01676393(00)00009-1

Okazaki, W. (2018). Hidesumasukei no kinou ni Yoru Bunrui Houhou no Kentou_Jouiteki Taido to Kikite Meatesei no Kanten kara. Hyougo Kyouiku Daigaku Kenkyuu Kiyou, 52, 19-31.

Otsuka, Y. (2004). Terebi Touron Bangumi ni Okeru Buntai Kirikae no Kouka -Poraitonesu no Kanten kara-. The Annals of Gifu Shotoku Gakuen University Faculty of Foreign Languages, 43, 111-124.

Prayitno, H. D. (2017). Studi Sosiopragmatik. Muhammadiyah University Press.

Saito, J. (2010). Subordinates' use of Japanese plain forms: An examination of superior-subordinate interactions in the workplace. Journal of Pragmatics, 42(12), 3271-3282. https://doi.org/10.1016/i.pragma.2010.06.014

Shibuya, K. (2015). Kakikotoba ni Okeru Sutairu Seisei no Mekanizumu. The Japanese Journal of Language in Society, 18(1), 23-39.

Takamiya, Y. (2017). Futsuutai o KIchou toshita Shizen Danwa ni Okeru Teineitai ni tsuite; Fuman o Hyoumei Suru Appushifuto ni Chakumoku shite. Kotoba, 38, 9-10.

Taniguchi, M. (2004). Nihongo no Kouen no Danwa ni Okeru Supiichi Reberu Shifuto no Keitai. Waseda Daigaku Nihongo Kyouiku Kenkyuu, 4, 117-129.

Terao, A. (2010). Bunmatsu Keishiki no Un'you to Sutairu Kirikae: Nihongo o Manabu Chuugokugo Bogo Washa no Juudan Deeta kara. Handai Nihongo Kenkyuu, 22.

Yasutake, T. (2010). Communication and Style Shift in Japanese. Aichi Kyouiku Kenkyuu Houkoku (Jinbun Kagaku Hen), 59, 7-14. 